Original article

https://www.journal-imab-bg.org

\title{
SUGGESTION FOR AN OPTIMAL MODEL FOR E.COLI, S. AUREUS AND C. ALBICANS PRESER- VATION AT A STORAGE TEMPERATURE IN THE RANGE OF $4^{\circ} \mathrm{C}$ TO $-20^{\circ} \mathrm{C}$
}

\author{
Neli Ermenlieva ${ }^{1}$, Emilia Georgieva ${ }^{2}$, Gabriela Tsankova ${ }^{1}$, Tatina Todorova ${ }^{1}$, \\ Silvia Mihaylova ${ }^{3}$ \\ 1) Department of Microbiology and Virology, Faculty of Medicine, Medical Uni- \\ versity of Varna, Bulgaria. \\ 2) TRS Medical laboratory assistant, Medical college, Medical University of \\ Varna, Bulgaria. \\ 3) TRS Assistant Pharmacist, Medical College, Medical University of Varna, \\ Bulgaria.
}

\begin{abstract}
The low temperature in the storage processes can vary in the range of $+4^{\circ} \mathrm{C}$ to $-80^{\circ} \mathrm{C}$ and even lower, using liquid nitrogen. Depending on this, the time for which we expect the microbial culture to remain viable also changes. Agar slant culture, covered with oil, stab culture, saline suspension, glycerol and DMSO preservation, drying on silica gel, drying on soil, sterile water, lyophilization, cryopreservation, etc. are methods employed for the preservation of microorganisms. However, the choice of method to be used depends on the type of microorganism, the purpose of storage, and duration of preservation.

The aim of the study is to compare storage techniques using semisolid agar and cultivation at $4^{\circ} \mathrm{C}$ and using BHI broth with glycerol and cultivation at $-20^{\circ} \mathrm{C}$. These are two commonly used and accessible methods for bacteria and yeast preservation.

After performing the storage procedure for a total of 18 strains of S. aureus, E. coli and C. albicans, we re-cultivated them after two and six months of preservation.

From the obtained results, we can conclude that the storage of bacteria at $4^{\circ} \mathrm{C}$ on semisolid agar for up to 8 weeks is successful, in C. albicans, one of the tested six strains did not survive. After 6 months, another strain of the yeasts did not show growth, as well as one of the sixth E. coli strains.

Storing microbes at $-20^{\circ} \mathrm{C}$ with a cryoprotectant has proven to be a more successful method. This was an expected result, and other authors commented that lower storage temperatures provide longer life for microorganisms.
\end{abstract} methods,

Keywords: bacteria, yeast, optimal model, storage

\section{INTRODUCTION}

Storage of bacterial strains is part of the laboratory work with microorganisms. For a shorter period of time, within 2-3 weeks, the bacterial and yeast strains can be stored on standard agar plate cultures placed in a refrigerator at $4^{\circ} \mathrm{C}$. This method is recommended for cultures that are used regularly. To minimize contamination and drying of the agar, culture plates should be sealed and stored upside down. If necessary, the bacteria are transferred to fresh agar or liquid medium and cultured overnight in an incubator at the appropriate temperature.

For longer-term storage, within months and years, it is necessary to create special aseptic conditions to ensure the survival of the target microorganisms. In general, the techniques for long-term storage of bacteria include three main steps:

1. Providing conditions for microbial introduction into the log phase, through the so-called enrichment, in which a bacterial or yeast culture is cultivated overnight in a broth medium;

2. Providing cryoprotectant in the medium protects the cells when the water content in them freezes and preserves their vitality;

3. Freezing (and sometimes drying) of the microbial culture, usually maintaining the lower temperature, keeps the bacteria alive for a longer period of time.

For the purpose of enrichment of the bacterial culture, it's necessary to select a suitable liquid medium. A bacterial colony from pure culture should be aseptically transferred into the broth, and the tube is cultured overnight in an incubator. If the target microbial cells are aerobic or facultative anaerobes, the caps of the tubes are left slightly open, or lignin plugs are used.

Some authors accepted that cells from the maximum stationary phase cultures are more resistant to damage by freezing and thawing than cells from the early or mid-log phase of growth [1].

The most common cryoprotectant used in the 
preparation of frozen liquid suspensions of microbiota is glycerol (final concentration of 15\%) [2, 3, 4]. DMSO (5$10 \%$ ), skim milk [5], and others are also commonly used. They have the cell-penetrating capacity [6] and prevent damages to the cells caused by ice crystal formation during the low temperature preservation.

The low temperature in the storage processes can vary in the range of $+4^{\circ} \mathrm{C}$ to $-80^{\circ} \mathrm{C}$ and even lower, using liquid nitrogen. Depending on this, the time for which we expect the microbial culture to remain viable also changes. Agar slant culture, agar slant culture covered with oil, stab culture, saline suspension, glycerol and DMSO preservation, drying on silica gel, drying on soil, sterile water, lyophilization, cryopreservation, etc. are methods employed for the preservation of microorganisms. However, the choice of method to be used depends on the type of microorganisms, the purpose of storage, and duration of preservation [7]. In the laboratory environment, we do not always have a $-80^{\circ} \mathrm{C}$ freezer, liquid nitrogen, lyophilization equipment and other more specific consumables. But some of the procedures are easy, require a shortlist of materials and also provide optimal results. Such is the longterm storage of microbes in a refrigerator at $4{ }^{\circ} \mathrm{C}$ or in a $20^{\circ} \mathrm{C}$ freezer, in a solution with different types of cryoprotectant.

The storage at $4{ }^{\circ} \mathrm{C}$ using stab cultures ensures the survival of microorganisms between three weeks to a year [8], the implementation of the procedures is easy and does not require the presence of special consumables. A commonly used method is to store microbes at $-20^{\circ} \mathrm{C}$ in a suitable medium with glycerol. The method provides survival of 1 to 2 years [9]. According to the protocol of OPS Diagnostic, to activate bacteria, only a couple of beads need to be removed from the tube. The tube doesn't need to be thawed. Otherwise, frozen microorganisms can be revived by thawing at $37^{\circ} \mathrm{C}$ and inoculation in a fresh medium.

Regarding the selection of a suitable nutrient medium for the storage of strains, according to some authors, one should be chosen, which would ensure maximum growth. ccording to others [10], the medium should support the survival of microorganisms but minimize theit metabolic processes and slow their rate of growth. Of course, extreme environments should be avoided because microbes have the ability to adapt through mutation events in order to survive in suboptimal surroundings.

\section{PURPOSE}

During our literature search, we found a number of protocols that describe procedures for storing bacterial strains and fungi. However, we did not find detailed information on the most suitable nutrient media that ensure the maximum survival of microorganisms. The aim of the study is to compare two commonly used and accessible methods for bacteria and yeast preservation and to use different nutrient media for cultivation to establish the most successful storage procedure.

\section{MATERIALS AND METHODS}

The study was conducted in a training microbiological laboratory in Medical university-Varna, Bulgaria, in the period May-December 2020. We investigated the storage properties of Escherichia coli (6 isolates), Staphylococcus aureus (6 isolates) and Candida albicans (6 isolates). For the storage of the microorganisms, we applied the following techniques - stabs cultures preparation in semisolid agar, stored at $4{ }^{\circ} \mathrm{C}$ in refrigerator and preservation in $15 \%$ glycerol with subsequent freezing of the bacterial culture at $-20^{\circ} \mathrm{C}$.

Storage technique using semisolid agar and cultivation at $4^{\circ} \mathrm{C}$

In the first technique, bacterial and yeast cultures were stored as stabs in screw capped vials. The vials were filled with a $3 \mathrm{ml}$ agar medium and sterilized. The microbes were introduced into the solidified agar with a sterile needle. The culture was incubated overnight with loose caps, then we poured a small amount of liquid paraffin on the agar and stored at $4{ }^{\circ} \mathrm{C}$ with tight caps. Incubated the culture was overnight with loose caps, then we poured a small amount of liquid paraffin on the agar and stored it at $4{ }^{\circ} \mathrm{C}$ with tight caps.

After two months or six months of preservation, we opened the cultures; we carefully poured the paraffin and transferred part of the cells into two types of broth media with a bacterial needle. After overnight incubation at $37^{\circ} \mathrm{C}$, we transferred the microbes and made seeds with each microorganism on two types of agar media, and they were cultivated under the same conditions. The next day, all cultures were examined for microbial growth. Each microorganism was microscopically and biochemically tested to prove the characteristic morphology and biochemical activity of the strains. Figure 1 shows the approaches described above.

Storage technique using BHI broth with glycerol and cultivation at $-20^{\circ} \mathrm{C}$

The tubes were filled with $2 \mathrm{ml}$ brain heart infusion broth and sterilized. We imported 500ìl standardized to $10^{7} \mathrm{CFU} / \mathrm{ml} \log$ phase microbial culture into the liquid medium and prepared a $15 \%$ glycerol solution (for $C$. albicans $-10 \%$ glycerol solution). The glycerol was autoclave-sterilized at $121^{\circ} \mathrm{C} / 15 \mathrm{~min}$. Then we mixed the components using a vortex mixer and placed the tubes in the freezer at $-20^{\circ} \mathrm{C}$.

After two months or six months of preservation, we opened the cultures and transferred part of the cells into two types of broth media. After overnight incubation at $37^{\circ} \mathrm{C}$, we transferred the microbes and made seeds with each microorganism on two types of agar media, and they were cultivated under the same conditions. The next day, all cultures in a solid medium were examined for microbial growth. All microorganisms were tested microscopically and biochemically. Figure 1 shows the approaches described above. 
Fig. 1. Procedure for storing microbial strains Staphylococcus aureus, Escherichia coli and Candida albicans
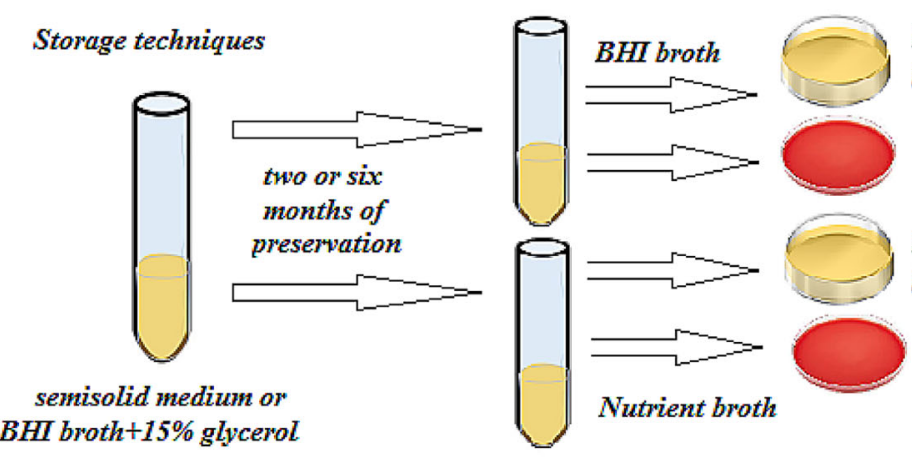

Nutrient agar

for $S$. aureus

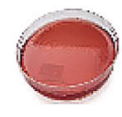

$E M B$

for $E$. coli

Sabouraud agar

for $C$ : albicans

Blood agar

Nutrient agar

for S. aureus

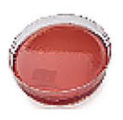

$E M B$

for $E$. coli

Blood agar

stab cultures and BHI broths with glycerol were opened and

RESULTS AND DISCUSSION

inoculated in fresh media two times for 48 hours. The survival of the strains was reported on each step of the procedure; the results are presented in Table 1.

18 strains of $S$. aureus, $E$. coli and $C$. abbicans, we re-cu tivated them after two and six months of preservation. The

Table 1. The storage properties of E. coli, S. aureus and C. albicans after two and six months of preservation under two types of storage conditions.

\begin{tabular}{|c|c|c|c|c|c|}
\hline \multicolumn{6}{|c|}{ Escherichia coli } \\
\hline \multirow{8}{*}{$\begin{array}{l}\text { Semisolid agar, } \\
4^{\circ} \mathrm{C}\end{array}$} & \multirow[t]{4}{*}{$2 \mathrm{~m}$} & \multirow[t]{2}{*}{$\mathrm{NB}$} & \multirow[t]{2}{*}{+6 isolates } & BA & +6 isolates \\
\hline & & & & EMB & +6 isolates \\
\hline & & \multirow[t]{2}{*}{$\mathrm{BHI}$} & \multirow[t]{2}{*}{+6 isolates } & BA & +6 isolates \\
\hline & & & & EMB & +6 isolates \\
\hline & \multirow[t]{4}{*}{$6 \mathrm{~m}$} & \multirow[t]{2}{*}{ NB } & \multirow{2}{*}{+5 isolates $; \times 1$ isolate } & $\mathrm{BA}$ & +5 isolates $; \times 1$ isolate \\
\hline & & & & EMB & +4 isolates $; \times 2$ isolates \\
\hline & & \multirow[t]{2}{*}{$\mathrm{BHI}$} & \multirow{2}{*}{+5 isolates $; \times 1$ isolate } & $\mathrm{BA}$ & +5 isolates $; \times 1$ isolate \\
\hline & & & & EMB & +5 isolates $; \times 1$ isolate \\
\hline \multirow{8}{*}{$\begin{array}{l}\mathrm{BHI}+\text { glycerol, } \\
-20^{\circ} \mathrm{C}\end{array}$} & \multirow{4}{*}{$2 \mathrm{~m}$} & \multirow[t]{2}{*}{ NB } & \multirow[t]{2}{*}{+6 isolates } & $\mathrm{BA}$ & +6 isolates \\
\hline & & & & EMB & +6 isolates \\
\hline & & \multirow[t]{2}{*}{$\mathrm{BHI}$} & \multirow{2}{*}{+6 isolates } & $\mathrm{BA}$ & +6 isolates; \\
\hline & & & & EMB & +5 isolates $; \times 1$ isolate \\
\hline & \multirow[t]{4}{*}{$6 \mathrm{~m}$} & \multirow[t]{2}{*}{ NB } & \multirow[t]{2}{*}{+6 isolates } & $\mathrm{BA}$ & +6 isolates \\
\hline & & & & EMB & +6 isolates \\
\hline & & \multirow[t]{2}{*}{ BHI } & \multirow[t]{2}{*}{+6 isolates } & BA & +6 isolates \\
\hline & & & & EMB & +6 isolates \\
\hline \multicolumn{6}{|c|}{ Staphylococcus aureus } \\
\hline \multirow{8}{*}{$\begin{array}{l}\text { Semisolid agar, } \\
4^{\circ} \mathrm{C}\end{array}$} & \multirow[t]{4}{*}{$2 \mathrm{~m}$} & \multirow[t]{2}{*}{ NB } & \multirow[t]{2}{*}{+6 isolates } & $\mathrm{BA}$ & +6 isolates \\
\hline & & & & NA & +6 isolates \\
\hline & & \multirow[t]{2}{*}{$\mathrm{BHI}$} & \multirow[t]{2}{*}{+6 isolates } & $\mathrm{BA}$ & +6 isolates \\
\hline & & & & NA & +6 isolates \\
\hline & \multirow[t]{4}{*}{$6 \mathrm{~m}$} & NB & +6 isolates & $\mathrm{BA}$ & +6 isolates \\
\hline & & & & NA & +6 isolates \\
\hline & & $\mathrm{BHI}$ & +6 isolates & $\mathrm{BA}$ & +6 isolates \\
\hline & & & & NA & +6 isolates \\
\hline BHI + glycerol, & $2 \mathrm{~m}$ & NB & +6 isolates & $\mathrm{BA}$ & +6 isolates \\
\hline$-20^{\circ} \mathrm{C}$ & & & & NA & +6 isolates \\
\hline & & $\mathrm{BHI}$ & +6 isolates & $\mathrm{BA}$ & +6 isolates \\
\hline & & & & NA & +6 isolates \\
\hline
\end{tabular}




\begin{tabular}{|c|c|c|c|c|c|}
\hline & \multirow[t]{4}{*}{$6 \mathrm{~m}$} & \multirow[t]{2}{*}{$\mathrm{NB}$} & \multirow[t]{2}{*}{+6 isolates } & $\mathrm{BA}$ & +6 isolates \\
\hline & & & & NA & +6 isolates \\
\hline & & \multirow[t]{2}{*}{ BHI } & \multirow[t]{2}{*}{+6 isolates } & BA & +6 isolates \\
\hline & & & & NA & +6 isolates \\
\hline \multicolumn{6}{|c|}{ Candida albicans } \\
\hline \multirow{8}{*}{$\begin{array}{l}\text { Semisolid agar, } \\
4^{\circ} \mathrm{C}\end{array}$} & \multirow[t]{4}{*}{$2 \mathrm{~m}$} & \multirow[t]{2}{*}{ NB } & \multirow[t]{2}{*}{+5 isolates $; \times 1$ isolate } & BA & +5 isolates $; \times 1$ isolate \\
\hline & & & & SA & +5 isolates $; \times 1$ isolate \\
\hline & & \multirow[t]{2}{*}{ BHI } & \multirow[t]{2}{*}{+6 isolates } & BA & +6 isolates \\
\hline & & & & SA & +6 isolates \\
\hline & \multirow[t]{4}{*}{$6 \mathrm{~m}$} & \multirow[t]{2}{*}{$\mathrm{NB}$} & \multirow[t]{2}{*}{+4 isolates $; \times 2$ isolates } & BA & +4 isolates $; \times 2$ isolates \\
\hline & & & & SA & +4 isolates; $\times 2$ isolates \\
\hline & & \multirow[t]{2}{*}{ BHI } & \multirow[t]{2}{*}{+6 isolates } & BA & +6 isolates \\
\hline & & & & SA & +6 isolates \\
\hline \multirow{8}{*}{$\begin{array}{l}\text { BHI + glycerol, } \\
-20^{\circ} \mathrm{C}\end{array}$} & \multirow[t]{4}{*}{$2 \mathrm{~m}$} & \multirow[t]{2}{*}{$\mathrm{NB}$} & \multirow[t]{2}{*}{+6 isolates } & BA & +6 isolates \\
\hline & & & & SA & +6 isolates \\
\hline & & \multirow[t]{2}{*}{ BHI } & \multirow[t]{2}{*}{+6 isolates } & BA & +6 isolates \\
\hline & & & & SA & +6 isolates \\
\hline & \multirow[t]{4}{*}{$6 \mathrm{~m}$} & \multirow[t]{2}{*}{$\mathrm{NB}$} & \multirow[t]{2}{*}{+5 isolates $; \times 1$ isolates } & BA & +5 isolates; $\times 1$ isolates \\
\hline & & & & SA & +5 isolates; $\times 1$ isolates \\
\hline & & \multirow[t]{2}{*}{ BHI } & \multirow[t]{2}{*}{+6 isolates } & BA & +6 isolates \\
\hline & & & & SA & +5 isolates; $\times 1$ isolates \\
\hline
\end{tabular}

Legend: (+) - microbial growth; $(x)$ - lack of microbial growth

NB - Nutrient broth; BA - Blood agar; EMB - Eosin methylene blue agar; NA - Nutrient agar; SA - Sabouraud agar; BHI - Brain heart infusion broth (for Candida albicans - supplemented with yeast extract $(0.5 \% \mathrm{w} / \mathrm{v}$ [BHIYE])

From the obtained results, we can conclude that the storage of bacteria at $4^{\circ} \mathrm{C}$ on semisolid agar for up to 8 weeks is successful, in C. albicans, one of the tested six strains did not survive. After 6 months, another strain of the yeasts did not show growth, as well as one of the sixth E. coli strains.

Storing microbes at $-20^{\circ} \mathrm{C}$ with a cryoprotectant has proven to be a more successful method. This was an expected result, and other authors commented that lower storage temperatures provide longer life for microorganisms [10]. In this technique, 17 of 18 microbial strains survived until the 6th month, only one isolate, C. albicans, does not show growth. We believe that it is possible that the reason is in the liquid nutrient medium that we used to cultivate the fungus after the storage process. Other authors also point to the nutrient broth as possible but not so suitable for fungi [11].

Our study shows that after storing E. coli at $4^{\circ} \mathrm{C}$ in semisolid agar, a more successful technique is to cultivate the bacteria in an enriched nutrient medium, such as blood agar, rather than in Levin's formation (EMB). Two of the E. coli strains did not demonstrate survival of the differentiating medium.

S. aureus strains showed solid bacterial growth in both storage methods, in all liquid and solid culture me- dia used to "awaken" the strains.

Our study shows that $C$. albicans is stored successfully for a long period of time, at least six months, using both approaches for long-term storage. The most suitable nutrient media for restoring the activity of the strains, according to our research, are BHI broth and blood agar. On nutrient broth, four of the strains do not show growth. This confirms our statement above that this liquid medium is not suitable for the purposes of long-term Candida preservation. Other authors also believe that at $-20^{\circ} \mathrm{C}$ temperature of storage, the preservation times vary depending on the medium used $[1,9,12]$.

\section{CONCLUSION}

Our study shows that the storage of microorganisms on semisolid agar at $4{ }^{\circ} \mathrm{C}$ and in $15 \%$ glycerol solution at $20^{\circ} \mathrm{C}$ provide survival of E. coli, S. aureus and C. albicans for a period of at least 6 months. Semisolid agar and brain heart infusion broth are suitable nutrient media for the storage of tested strains. After the storage period, the strains can be successfully activated on blood agar, the choice of liquid media caught be BHI broth or nutrient broth, except for some strains of Candida albicans, which did not show growth of nutrient broth. 
REFERENCES:

1. Heckly RJ. Preservation of Microorganisms. Adv Appl Microbiol. 1978; 24:1-53. [PubMed]

2. Costello SP, Tucker EC, La Brooy J, Schoeman MN, Andrews JM. Establishing a fecal microbiota transplant service for the treatment of Clostridium difficile infection. Clin Infect Dis. 2016 Apr 1;62(7):908-14. [PubMed]

3. Kaito S, Toya T, Yoshifuji K, Kurosawa S, Inamoto K, Takeshita K et al. Fecal microbiota transplantation with frozen capsules for a patient with refractory acute gut graft-versushost disease. Blood Adv. 2018 Nov 27;2(22):3097-3101. [PubMed]

4. Satokari R, Mattila E, Kainulainen V, Arkkila PE. Simple faecal preparation and efficacy of frozen inoculum in faecal microbiota transplantation for recurrent Clostridium difficile infection - an observational cohort study. Aliment Pharmacol Ther. 2015 Jan;41(1):46-

\section{3. [PubMed]}

5. Bellali S, Khalil JB, Fontanini A, Raoult D, Lagier J-C. A new protectant medium preserving bacterial viability after freeze drying. Microbiol Res. 2020 Jun;236: 126454. [PubMed]

6. Prakash O, Nimonkar Y, Shouche YS. Practice and prospects of microbial preservation. FEMS Microbiol Lett. 2013 Feb;339(1):1-9. [PubMed]

7. Jain A, Jain R, Jain S. Preservation of Microorganisms: Stabs, Slants, Lyophilization and Cryopreservation. In: Basic Techniques in Biochemistry, Microbiology and Molecular Biology. Springer Protocols Handbooks. Humana, New York, NY. 28 February 2020. [Crossref]

8. Storing Bacterial Samples for Optimal Viability. ThermoFisher Scientific. [Internet]

9. Tedeschi R, De Paoli P. Collection and Preservation of Frozen Microorganisms. In: Methods in
Biobanking. Methods in Molecular Biology (Methods and Protocols). Dillner J. (eds). vol 675. Humana Press, Totowa, NJ. 28 February 2011., pp.313-26. [Crossref]

10. She RC, Cathy A. Petti CA. Procedures for the Storage of Microorganisms. In: Manual of Clinical Microbiology, 11th Edition. Book Editor(s): Jorgensen JH, Carroll KC, Funke G, Pfaller MA, Landry ML, Richter SS, Warnock DW. ASM Press. 15 May 2015. Chapter 11. p 161-168. [Crossref]

11. Moore JE, McMullan R. Comparison of media for optimal recovery of Candida albicans and Candida glabrata from blood culture. Ir J Med Sci. 2003 Apr-Jun;172(2):60-2. [PubMed]

12. Harbec PS, Turcotte P. Preservation of Neisseria gonorrhoeae at 20 degrees C. J Clin Microbiol. 1996 May;34(5):1143-6. [PubMed]

Please cite this article as: Ermenlieva N, Georgieva E, Tsankova G, Todorova T, Mihaylova S. Suggestion for an optimal model for E.coli, S. aureus and C. albicans preservation at a storage temperature in the range of $4{ }^{\circ} \mathrm{C}$ to $-20^{\circ} \mathrm{C}$. $J$ of IMAB. 2021 Oct-Dec;27(4):4038-4042. DOI: https://doi.org/10.5272/jimab.2021274.4038

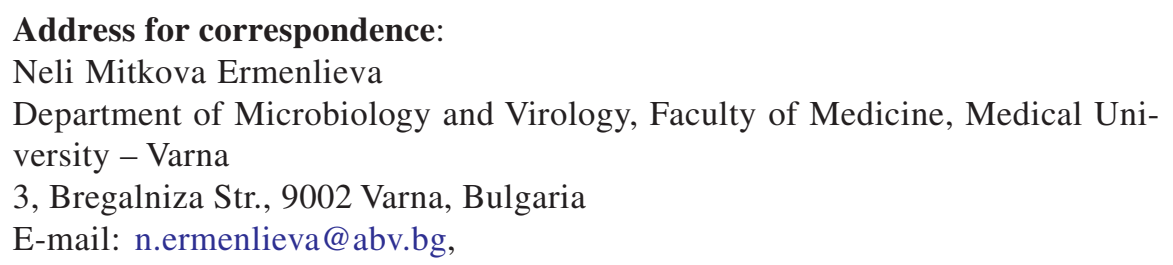

